\title{
Working in the Same Sector, in the Same Organization and in the Same Occupation: Similarities and Differences Between Women and Men Physicians' Work Climate and Health Complaints
}

I Helena Falkenberg'

PhD, Department of Psychology, Stockholm University, Sweden

I Katharina Näswall

Associate Professor, Department of Psychology, University of Canterbury, New Zealand

1 Petra Lindfors

Professor, Department of Psychology, Stockholm University, Sweden

I Magnus Sverke

Professor, Department of Psychology, Stockholm University, Sweden;

Faculty of Economic and Management Sciences, North-West University, South Africa

\begin{abstract}
Due to the segregated labor market, gender differences in health are often confounded by factors such as sector or occupation. This study explored similarities and differences in work climate and health complaints among women and men working in the same sector, in the same organization, and in the same occupation. First, work climate and health complaints were compared between women and men. Second, relations between the work climate and health complaints were investigated in both genders. Questionnaire data were collected from 95 women and 105 men physicians who worked in the same acute care hospital in Sweden. The results showed no gender differences in the job, role, leadership, or organizational characteristics. However women physicians reported less workgroup cohesiveness and cooperation and more mental and physical health complaints than men physicians. Workgroup cohesiveness and cooperation were related to less health complaints only for men physicians. This explorative study indicates similarities between women and men when the work situation is similar, but suggests that some of the differences that appear in the large structures of the gender-segregated labor market also seem to be present for women and men who work in the same sector, in the same organization, and in the same occupation.
\end{abstract}

\section{KEY WORDS}

Gender / health care / health complaints / physicians / Sweden / work climate

DOI

10.19154/njwls.v5i4.4844

\footnotetext{
${ }^{1}$ E-mail: hfg@psychology.su.se
} 


\section{Introduction}

lthough measures have been taken, in Sweden as in other countries, to improve equality between women and men, gender still divides the labor market both horizontally (women and men working in different sectors) and vertically (women and men working at different positions) (Campos-Serna et al. 2013; Eurostat 2008). This gender-segregation means that the differences that have been attributed to gender, for example in health, may be confounded with other factors such as the work environment that characterizes different sectors, occupations, or positions (Emslie et al. 1999; Liu et al. 2008). However, studies of women and men working in similar contexts are rare, probably due to the difficulties to find comparable samples of women and men in the same occupation and organization (Emslie et al. 1999; Lewis and Mathiassen 2013; Liu et al. 2008). The present study investigates work climate and health complaints among women and men during similar working conditions. Specifically, the women and men investigated in this study work in the same sector (health care), in the same organization (a Swedish hospital), and in the same occupation (physician).

\section{Work climate among women and men}

Several different theoretical models have been developed to describe the psychosocial work environment. The models focus on different aspects of the work situation, but demands and control (Karasek and Theorell 1990) or demands and resources (Bakker and Demerouti 2007) or effort-reward imbalance (Siegrist 1996) are among the frequently included aspects. One of the existing models that include the richest spectra of work characteristics is the theory of psychological work climate. James and Sells (1981) have described the psychological work climate as "individuals' cognitive representations of proximal environments" (p. 275). Five main domains of this psychological work climate have been specified, relating to job, role, leadership, workgroup, and organizational characteristics (James and James 1989; James and Sells 1981). Each of these five characteristics consists of several aspects of the work environment and a large range of measures have been developed to capture these aspects. The cognitive representations of the work climate have been described as not only being based on the present situation but also to be shaped and evaluated on the basis of past experiences (James and Sells 1981).

The fact that the perception of the work climate is dependent on both past and present experiences is relevant to consider when studying whether climate perceptions differ among women and men. If women and men have been exposed to systematic differences in the past, this would result in women and men conceptualizing the work climate somewhat differently, which is well known from cross-cultural studies (van de Vijver et al. 2011). Despite this, controlling for gender differences (invariance) in the measures of psychological work climate has been largely neglected in climate research. In fact, studies have seldom compared the work climate perceptions of women and men. For example, gender was not included in the first and exhaustive quantitative meta-analytic review of psychological climate and work outcomes (Parker et al. 2003) or mentioned when the European Journal of Work and Organizational Psychology dedicated a special issue to psychological work climate (D'Amato and Burke 2008).

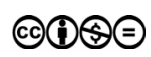




\section{Differences in health among women and men}

When women and men in Sweden rate their health, women generally report poorer health in terms of overall health status and subjective health complaints than do men (Statistics Sweden 2014). This pattern is repeated in most countries in Europe and elsewhere (Campos-Serna et al. 2013; Eurostat 2008). Gender differences in health seem to be smaller when women and men who work in similar sectors and occupations are compared (Emslie et al. 1999; Härenstam et al. 2000; Liu et al. 2008), but even when working in the same occupation, women still tend to report more health complaints than men (Lewis and Mathiassen 2013). However, when women and men perform similar or identical work tasks, similarities in psychological and physical reactions have been found (Persson et al. 2009).

Gender differences have been found in predictors of stress and ill-health, where lack of communication and support from supervisors as well as interpersonal conflicts, work-family conflict, and workload have been associated with more symptoms of stress among women in high positions (Lundberg and Frankenhaeuser 1999; Narayanan et al. 1999). In contrast, lack of control over the work situation, inefficient use of time, and lack of social support have been shown to predict health problems among men working in high positions (Muhonen and Torkelson 2003; Narayanan et al. 1999).

There are several potential reasons for health differences between women and men having the same occupation. Some explanations suggest that women are exposed to more stress than men, also when they work in the same occupation, since women have higher demands and obligations in their social roles, which has been expressed in the different exposure hypothesis (Liu et al. 2008; McDonough and Walters 2001). Also, the total workload for working women could be higher than for working men since women more often have the main responsibilities for domestic tasks (Eurostat 2008; Krantz et al. 2005; Lundberg and Frankenhaeuser 1999; World Economic Forum 2014). However, the actual work tasks that women and men are to perform in the same occupation may also differ (Härenstam et al. 2000; Lewis and Mathiassen 2013). Another explanation that has been suggested involves the different vulnerability hypothesis, which suggests that women are more vulnerable to life events and stressors than men, even if they experience the same amount of stressors (McDonough and Walters 2001; Roxburgh 1996).

\section{Women and men physicians}

Physicians constitute an occupational group exposed to a challenging working life, with high demands of adequate decision-making, efficiency, and a constant need for adaptation to new technology, new knowledge, and recurring changes (Arnetz 2001; Edwards et al. 2002). Gender has been concluded to influence the decisive choices women and men make throughout their careers, from training to practice (Eriksson 2003; Jefferson et al. 2015; Risberg 2004; Riska 2001; West 1993). Women, working as physicians, have been found to report specific stressors such as discrimination, lack of female role models, role strain, and overload (De Koninck et al. 1997; Robinson 2003). Special attention has been paid to the difficulties of combining parenthood with working as a physician, especially for women (De Koninck et al. 1997; Eriksson 2003). 


\section{The present study}

Considering the fact that women and men to a large extent work in different sectors, occupations, and positions and that these differences might impact on the work environment and health among women and men, the aim of the present study was to explore similarities and differences between women and men who have similar working conditions (working in the same sector, in the same organization, and in the same occupation). Women and men were compared regarding 1) levels of psychological work climate and health complaints and 2) how the work climate related to health complaints. This was investigated among 95 women and 105 men physicians who worked in the same acute care hospital in Stockholm, Sweden, and by adjusting for a variety of potential gender differences.

\section{Method}

\section{Data collection and participants}

Questionnaires along with a cover letter explaining the purpose of the study were sent to the home addresses of all physicians at an acute care hospital in the Stockholm region in Sweden in the year 2001. The cover letter also informed study participants that their responses would be treated confidentially and that participation was entirely voluntary. A second letter, in which hospital management expressed its support for the survey, and a pre-addressed, postage-paid return envelope were also included in the mailing. The questionnaires were sent to all 351 physicians at the hospital and $239(68 \%)$ responded. The responses from 10 physicians (six women and four men) were excluded after examining the data for multivariate outliers in all study variables. Another 15 women and 14 men were excluded due to a too large proportion of missing responses, resulting in an effective sample size of 95 women and 105 men.

Women and men differed significantly in organizational tenure, supervisory position, and employment contract. On average, women had been working 6 years $(S D=6$ range: $0-30)$ at the hospital, while the average tenure of men was 11 years $(S D=10$, range: $0-39)(t[198]=4.14, \mathrm{p}<0.001)$. Among the women, $15 \%$ had a supervisory position compared with $29 \%$ of the men $\left(\chi^{2}[1]=4.79, \mathrm{p}<0.05\right)$ and a total of $61 \%$ of the women physicians were permanently employed compared to $85 \%$ of the men $\left(\chi^{2}[1]=10.17, \mathrm{p}<0.001\right)$.

\section{Measures}

Five domains of psychological work climate were specified: job, role, workgroup, leadership, and organizational characteristics. Each characteristic consisted of three variables, except workgroup characteristics that consisted of two variables. Health complaints were measured with the variables of mental health complaints and physical health complaints. The following background variables were also included: organizational tenure; whether the person had any form of supervisory position, and employment contract. Table 1 provides a description of the variables and Table 2 presents descriptive statistics 


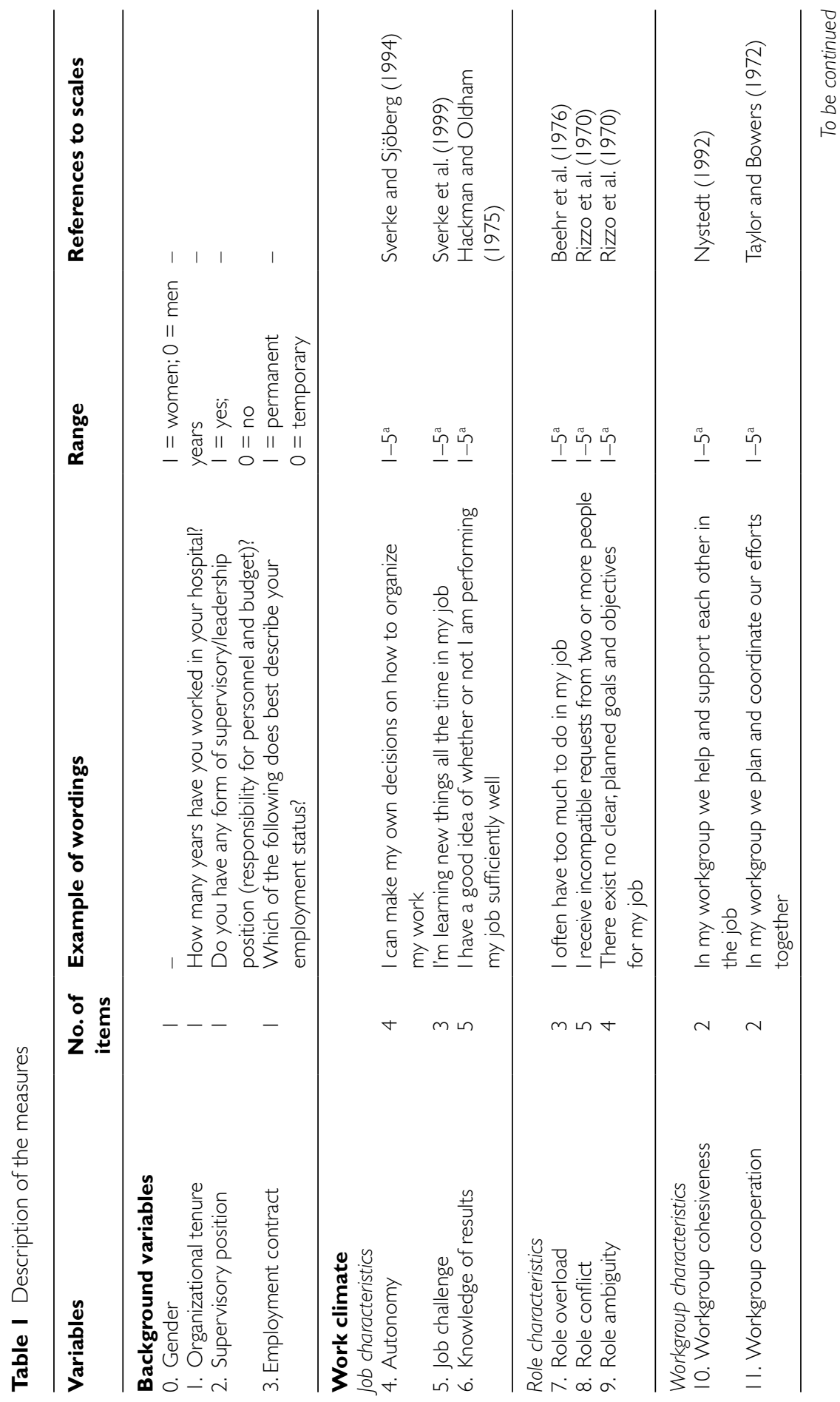




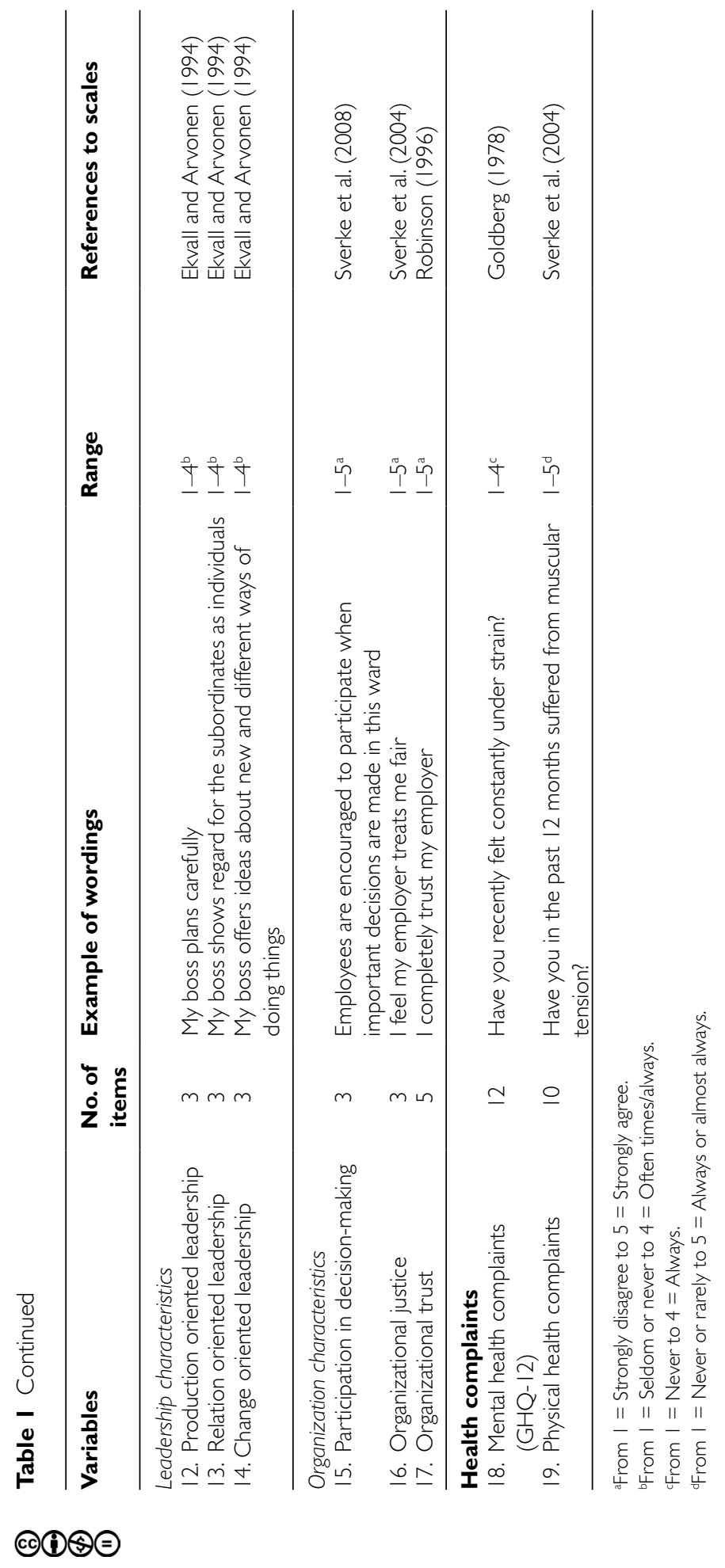




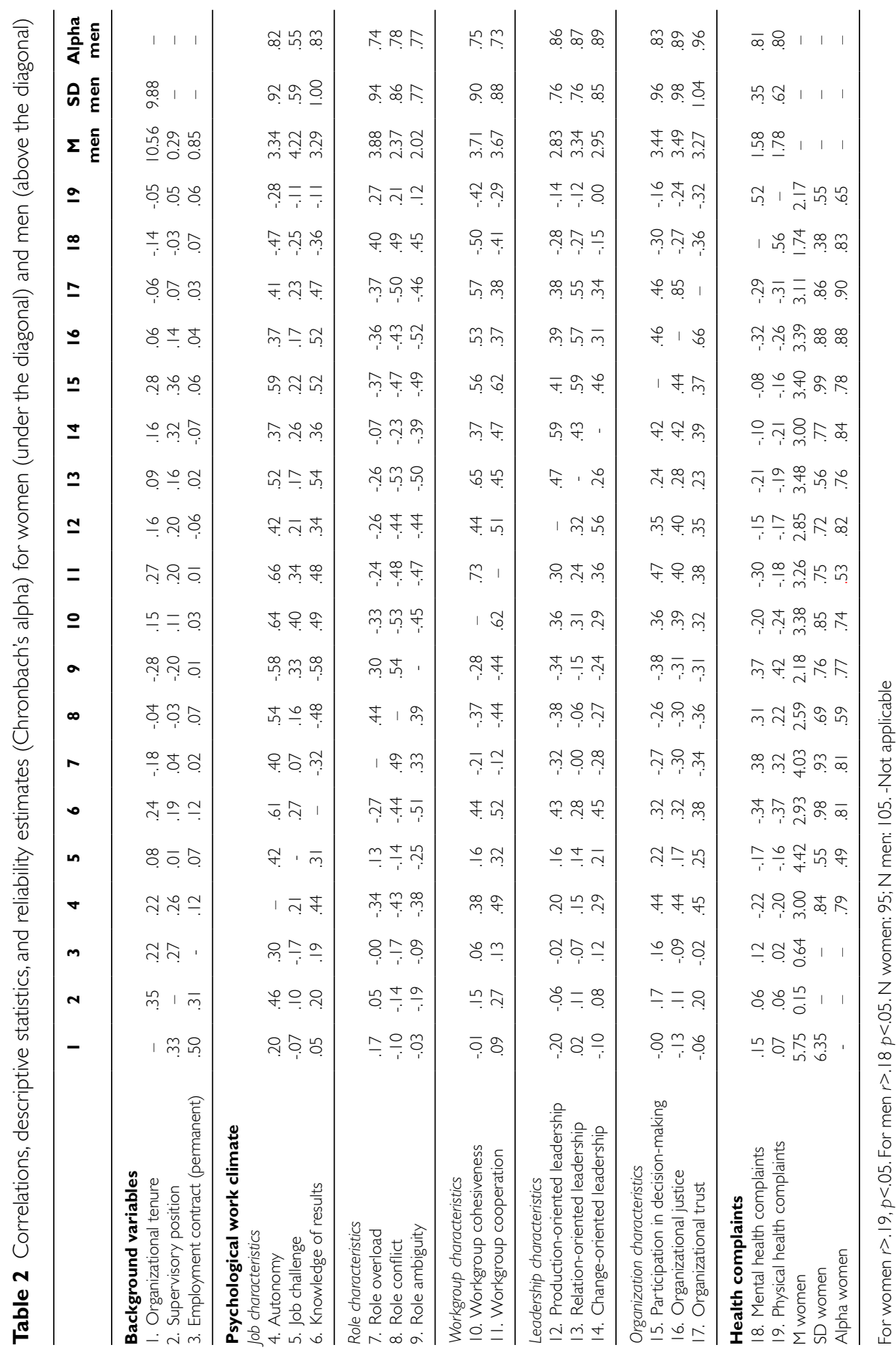


and reliability estimates of all study variables for both women and men. Most of the reliability coefficients (Cronbach's alpha) (Cronbach 1951) were above 0.70 with some exceptions (role conflict, workgroup cooperation, and organizational commitment for women and job challenge for women and men), which indicate acceptable reliability (Nunnally 1978).

\section{Data Analyses}

\section{Work climate}

In order to test invariance of the measures between women and men, we first tested whether the factor covariances and variances differed between the genders. If covariance matrices do not differ across groups, measurement invariance is established and further tests of measurement invariance are usually not necessary (Vandenberg and Lance 2000). In our sample, factor variances/covariances did not differ between the genders (see Table 3). However, we still wanted to test whether other aspects of measurement were also invariant. To do this, we computed multi-group (for women and men) confirmatory factor analyses, using the robust maximum likelihood estimation procedures in Lisrel 8.7. Invariance tests of factor loadings showed that women and men, to some extent, emphasized different aspects of the work climate. Differences appeared for the variables of autonomy, role conflict, relation-oriented leadership, organizational justice, and trust (see Table 4). In order to take into account that

Table 3 Test of measurement invariance between women and men of work climate as a five-factor model

\begin{tabular}{|c|c|c|c|c|c|c|c|c|c|}
\hline \multirow[b]{2}{*}{ Model } & \multirow[b]{2}{*}{ df } & \multirow[b]{2}{*}{$\chi^{2}$} & \multirow[b]{2}{*}{ RMSEA } & \multirow[b]{2}{*}{ SRMR } & \multirow[b]{2}{*}{ CFI } & \multirow[b]{2}{*}{ CAIC } & \multicolumn{3}{|c|}{ Model comparison } \\
\hline & & & & & & & $\Delta$ Model & $\Delta \mathbf{d f}$ & $\Delta \chi^{2}$ \\
\hline $\begin{array}{l}\text { a. Multi group. Freely } \\
\text { estimated }\end{array}$ & 134 & 370.15 **** & .109 & .10 & .95 & 879.13 & - & - & - \\
\hline $\begin{array}{l}\text { b. Multi group. Equal } \\
\text { factor variances } \\
\text { and covariances }\end{array}$ & 144 & $384.93 * * * *$ & .106 & .10 & .95 & 826.94 & b vs. a & 10 & 14.78 \\
\hline $\begin{array}{l}\text { c. Multi group. Equal } \\
\text { factor variances/ } \\
\text { covariances and } \\
\text { factor loadings }\end{array}$ & 158 & 432.27米米 & .108 & .13 & .94 & 780.52 & c vs. b & 14 & 47.34 **** \\
\hline $\begin{array}{l}\text { d. Multi group. Equal } \\
\text { factor variances/ } \\
\text { covariances, factor } \\
\text { loadings, and } \\
\text { error terms }\end{array}$ & 172 & $441.68^{* * * * *}$ & .103 & .12 & .94 & 696.17 & d vs. c & 14 & 9.41 \\
\hline
\end{tabular}

****** $p<.001$.

$\mathrm{N}$ women $=95 ; \mathrm{N}$ men $=105$. 
Table 4 Factor loadings of work climate for women and men

\begin{tabular}{|c|c|c|c|}
\hline & \multicolumn{2}{|c|}{ Factor loadings } & \multirow[b]{2}{*}{$\Delta \chi^{2 a}$} \\
\hline & Women & Men & \\
\hline \multicolumn{4}{|l|}{ Job characteristics } \\
\hline Autonomy & .59 & .88 & $9.08 * *$ \\
\hline Job challenge & .34 & .43 & .23 \\
\hline Knowledge of results & .76 & .72 & .30 \\
\hline \multicolumn{4}{|l|}{ Role characteristics } \\
\hline Role overload & .52 & .49 & .46 \\
\hline Role conflict & .58 & .77 & $6.44 *$ \\
\hline Role ambiguity & .65 & .77 & 2.19 \\
\hline \multicolumn{4}{|l|}{ Workgroup characteristics } \\
\hline Workgroup cohesiveness & .71 & .90 & 3.01 \\
\hline Workgroup cooperation & .75 & .85 & 2.29 \\
\hline \multicolumn{4}{|l|}{ Leadership characteristics } \\
\hline Production-oriented leadership & .71 & .68 & .58 \\
\hline Relation-oriented leadership & .35 & .85 & 15.50****** \\
\hline Change-oriented leadership & .68 & .62 & .75 \\
\hline \multicolumn{4}{|l|}{ Organization characteristics } \\
\hline Participation in decision-making & .58 & .50 & .99 \\
\hline Organizational justice & .76 & .94 & $4.55^{*}$ \\
\hline Organizational trust & .68 & .97 & $10.62 * *$ \\
\hline
\end{tabular}

All factor loadings were significant: $p<.05$.

Variances and covariances of the latent factors were constrained to be equal for women and men.

aTest for difference in factor loadings between women and men $\left(\Delta \chi^{2} ; \Delta d f=1\right)$, between a model with freely estimated factor loadings and a model wherein each estimate was held constant between women and men.

* $\mathrm{p}<.05$; *** $<.01 ; * * * * \mathrm{p}<.001$.

women and men perceived the aspects of the working climate somewhat differently, each dimension of the work climate (job, role, workgroup, leadership, and organization) was formed by averaging the included variables, weighted by the factor scores from the confirmatory factor analyses for women and men. For example, the latent factor for the job characteristics was calculated as follows for women: [(women's mean of autonomy * 0.59) + (women's mean of job challenge *0.34) + (women's mean of knowledge of results *0.76)/3], and for men: [(men's mean of autonomy*0.88)+ $($ men's mean of job challenge * 0.43$)+($ men's mean of knowledge of results * 0.72$) /$ 3]. Table 4 summarizes all factor loadings for women and men. The table also reports tests of differences in factor loadings between women and men, using chi-square difference tests between freely estimated factor loadings and a model wherein the estimates were held constant between women and men. Significant chi-square differences mean that there were gender differences in factor loadings. There were no differences in the error terms between women and men (see Table 3). 


\section{Test of mean-level differences between women and men}

Two multivariate analyses of covariance (MANCOVA) were performed to test for mean differences between women and men, using organizational tenure, supervisory position, and employment contract as covariates. The first analysis compared the work climate characteristics (job, role, workgroup, leadership, and organizational characteristics) between women and men (while considering gender differences in factor loadings as described above). The second analysis compared health complaints (mental and physical health complaints) between women and men with the same covariates.

\section{The associations between work climate and health complaints among women and men}

Multiple regression analyses were conducted separately for women and men to predict health complaints (mental and physical health complaints) from the work climate factors (job, role, workgroup, leadership, and organizational characteristics), again controlling for differences in factor loadings between woman and men. Organizational tenure, supervisory position, and employment contract served as control variables. Multiplegroup tests in Lisrel 8.7 were conducted in order to test whether the regression weights and the amount of variance explained differed significantly between the genders.

\section{Results}

\section{Test of mean-level differences between women and men}

\section{Work climate}

The results showed a significant multivariate main effect of gender $(F[5,191]=3.08$, $p<.05)$, indicating an overall difference in work climate between the women and men physicians, when controlling for background variables and equivalence of the constructs (see Table 5). The only univariate effect of gender appeared for workgroup characteristics where women physicians reported a significantly lower mean level than men physicians. Women physicians thus reported less workgroup cohesiveness and cooperation than men physicians.

\section{Health complaints}

There was a significant multivariate difference between the genders in health complaints after controlling for supervisory position, organizational tenure, and employment contract $(F[2,194]=10.16, p<.001)$ (see Table 5). Both variables of health complaints differed between women and men, with women physicians reporting more mental and more physical health complaints. 
Table 5 Test for mean differences between women and men in work climate and health complaints

\begin{tabular}{|c|c|c|c|c|c|c|}
\hline & \multicolumn{2}{|c|}{ Mean level } & \multicolumn{4}{|c|}{ Univariate F-tests } \\
\hline & Women & Men & Gender $^{a}$ & Tenure $^{a}$ & $\begin{array}{c}\text { Supervisory } \\
\text { position }^{\mathrm{a}}\end{array}$ & $\begin{array}{c}\text { Employment } \\
\text { contract }^{\mathrm{a}}\end{array}$ \\
\hline \multicolumn{7}{|l|}{ Work climate } \\
\hline Job characteristics & 1.96 & 2.11 & 1.80 & 2.45 & $10.76 * *$ & .03 \\
\hline Role characteristics & 1.78 & 1.66 & 1.88 & 2.01 & .77 & .06 \\
\hline Workgroup characteristics & 2.67 & 2.96 & $6.32 *$ & 2.19 & $4.17 *$ & .06 \\
\hline Leadership characteristics & 2.01 & 1.96 & 1.14 & .10 & $7.54 * *$ & 1.25 \\
\hline Organization characteristics & 2.43 & 2.51 & .42 & .37 & $7.84 * * *$ & .07 \\
\hline \multicolumn{7}{|l|}{ Health complaints } \\
\hline Mental health complaints & 1.74 & 1.58 & $10.28 * * *$ & .60 & .00 & 2.27 \\
\hline Physical health complaints & 2.17 & 1.78 & 19.44***** & .11 & .86 & .14 \\
\hline
\end{tabular}

*p $<.05 ; * *$ * $<.01 ; * * * * 0.001$. N women: 95 ; men: 105.

Scale range $I-5$ for all variables, except leadership ( $\mid-4)$ and mental health complains (0-3).

anivariate F-tests, df: [1, 195].

Multivariate effects for work climate: Gender $F[5,191]=3.08, p<.05$; tenure $F[5,191]=1.75$, ns; supervisory position $F[5,191]=3.50, p<.05 ;$ employment contract $F[5,191]=.40$, ns.

Multivariate effects for health complaints: Gender $F[2,194]=10.16, p<.001$; tenure $F[2,194]=.31$, ns; supervisory position $F[2,194]=.63$, ns; employment contract $F[2,194]=2.10$, ns.

\section{The associations between work climate and health complaints among women and men}

The next set of analyses concerned the prediction of health complaints from the five previously described dimensions of work climate, when controlling for organizational tenure, supervisory position, and employment contract. Table 6 presents the results of the regression analyses.

For women physicians, the only significant predictor of health complaints was role characteristics (i.e., role stress), which were associated with more mental and more physical health complaints. Also for men physicians, role characteristics were positively associated with mental health complaints, but there was no association with physical health complaints. Workgroup characteristics predicted lower levels of mental and physical health complaints only for men. This implies that more workgroup cohesiveness and cooperation contributed to less health complaints, but only for men physicians. Workgroup was the only dimension for which the effect size in predicting health complaints differed significantly between women and men physicians. Leadership characteristics predicted physical health complaints among men physicians, but it should be noted that while in the multiple regression analyses the effect of leadership characteristics on physical health complaints was positive (shown in Table 6), the bivariate associations between leadership variables and health complaints were all negative (shown in Table 2). This result is most likely representing a suppressor effect.

In total, the model variables accounted for $22 \%$ of the variance in mental health complaints for women physicians and $34 \%$ of the variance for men physicians. The total 
Table 6 Multiple regression analyses predicting health complaints for women and men

\begin{tabular}{lrrrrrr}
\hline & \multicolumn{3}{c}{ Mental health complaints } & \multicolumn{2}{c}{ Physical health complaints } \\
\hline & Women & Men & \multicolumn{1}{c}{$\chi^{2}$} & Women & Men & \multicolumn{1}{c}{$\chi^{2}$} \\
\hline Background variables & & & & & & \\
Organizational tenure & .08 & -.00 & $.36^{\mathrm{a}}$ & .01 & -.01 & $.40^{\mathrm{a}}$ \\
Supervisory position & .13 & .00 & $.94^{\mathrm{a}}$ & .18 & .09 & $.09^{\mathrm{a}}$ \\
Employment contract (permanent) & .13 & .06 & $.26^{\mathrm{a}}$ & .05 & -.05 & $1.57^{\mathrm{a}}$ \\
\hline Work climate & & & & & & \\
Job characteristics & -.22 & -.06 & $.72^{\mathrm{a}}$ & -.26 & .09 & $2.38^{\mathrm{a}}$ \\
Role characteristics & $.38^{*} * *$ & $.48^{* * * *}$ & $.41^{\mathrm{a}}$ & $.28^{*}$ & .06 & $3.12^{\mathrm{a}}$ \\
Workgroup characteristics & -.07 & $-.34^{* *}$ & $2.50^{\mathrm{a}}$ & .02 & $-.47^{* * * *}$ & $4.88^{* \mathrm{a}}$ \\
Leadership characteristics & .16 & .20 & $.08^{\mathrm{a}}$ & .05 & $.28^{*}$ & $.51^{\mathrm{a}}$ \\
Organization characteristics & -.05 & .06 & $.41^{\mathrm{a}}$ & -.08 & -.20 & $.76^{\mathrm{a}}$ \\
R $^{2}$ (adj) & $.22^{* * * *}$ & $.34^{* * * *}$ & $6.05^{\mathrm{b}}$ & $.16^{* *}$ & $.15^{* *}$ & $12.76^{\mathrm{b}}$ \\
\hline
\end{tabular}

* p<.05; *** p .01; ***** $p<.001 ; \mathrm{n}$ women: $95 ; \mathrm{n}$ men 105.

A significant chi-square indicates that the magnitudes of effect size differ between women and men $\left({ }^{a} \mathrm{df}=1,{ }^{\mathrm{b}} \mathrm{df}=8\right)$.

variance explained for physical health complaints was $16 \%$ for women and $15 \%$ for men physicians.

None of the background variables (organizational tenure, supervisory position, and employment contract) were significantly related to mental or physical health complaints.

\section{Discussion}

\section{Similarities and differences in work climate and health complaints between woman and men}

The present study investigated women and men working in the same sector, in the same organization, and in the same occupation in order to compare their work climate and health complaints during rather similar working conditions. Women and men physicians reported similar mean levels of job, role, leadership, and organizational characteristics. However, there was a difference in workgroup characteristics. Women physicians reported less workgroup characteristics, which means that women perceived workgroups as being less cohesive and less cooperative than men. This is in line with previous research suggesting that gender roles may complicate social relations for women physicians (Risberg 2004; Riska 2001). Specifically, previous research has shown that women working as physicians tend to be excluded from formal and informal networks (Miller and Clark 2008). Physician colleagues and registered nurses have also been shown to have higher expectations of helpfulness from women physicians than from men physicians (Eriksson 2003; West 1993). 
In line with other studies investigating women and men with similar working conditions (Emslie et al. 1999; Härenstam et al. 2000; Lewis and Mathiassen 2013; Liu et al. 2008; Lundberg and Frankenhaeuser 1999; Muhonen and Torkelson 2003), women physicians in this study reported more health complaints than men (both mental and physical complaints). This study allows no conclusions regarding the reasons underlying the health differentials between women and men. However, the main difference in the work climate was found in the workgroup characteristics, while no differences was found in the role-, job-, leadership-, or organization characteristics. These results seem more in line with the different exposure hypothesis, which underscores gender differences in social demands and obligations, rather than with the vulnerability hypothesis, which suggests that women are more vulnerable to life events and stressors than men (McDonough and Walters 2001; Roxburgh 1996).

\section{The associations between work climate and health complaints among women and men}

The results of the regression analyses showed that role characteristics, which included overload, conflict, and ambiguity in the work role, were related to more mental and physical health complaints for women and with more mental health complaints for men. This is in line with previous research findings showing that role characteristics (also called role stress) are associated with ill-health of employees (James and Sells 1981; Parker et al. 2003). The results suggest that clarifying roles and reducing role overload and role conflicts are important to improve health among physicians. This holds for both genders but especially for women for whom role characteristics were associated with both more mental and more physical health complaints.

The gender difference found in the mean level of workgroup characteristics was also reflected in the prediction of health complaints. For men, more workgroup cohesiveness and cooperation were related to less health complaints (both less mental and less physical health complaints), but for women, the workgroup did not contribute to fewer health complaints. Using the workgroup as a resource for reducing health complaints is in line with previous research that emphasizes the importance of the social context at work for health (André-Petersson et al. 2007; Härenstam et al. 2000; Johnson et al. 1989). Considering that this was the case only for the men underline the importance of gender aspects in social relations.

\section{Limitations}

In spite of the many measures taken to improve the comparability between women and men, this study was not capable of considering all possible gender differences. Thus, the present study did not control for horizontal segregation in this specific occupation (i.e., that women and men often work as physicians in different specialties) or that women and men may perform different work tasks (Lewis and Mathiassen 2013). Additionally, it was beyond the scope of the present study to investigate explicitly demands relating to the nonwork domain, where women have been shown to have a higher workload due to more responsibilities for home and family (e.g., Eurostat 
2008; Krantz et al. 2005). The fact that the data came from a rather small sample of women and men who were working in one specific profession, in a specific hospital, in a specific sector, in a specific country may of course limit the generalizability of the results to other contexts. However, here this can be considered an advantage in terms of similarities between the genders, which would otherwise have been difficult to obtain. A larger sample size would have allowed for analyzing data in more detail, but the difficulties in finding large and comparative samples of women and men who work in the same occupation and in the same organization have been addressed as a problem in previous research (Emslie et al. 1999; Lewis and Mathiassen 2013; Liu et al. 2008). Yet, additional research, preferable with larger samples, of women and men in similar situations should be encouraged. Moreover, the data were collected some time ago (2001) and the situation for women and men may have changed over the years. However, the global gender gap index (considering gender equality across health, education, economy, and politics) shows only marginal changes in Sweden since 2000 (World Economic Forum 2014), which indicates that gender equality has not evolved largely since the millennium shift. When it comes to the work situation, official statistics show that the work environment of physicians in 2013 seems to be rather similar to that in 2001 (Statistics Sweden 2002; Swedish Work Environment Authority 2014). Another important issue relates to the cross-sectional study design. However, the aim was not primarily to focus on causal relations but instead to compare different aspects between the genders at one occasion. Considering these limitations, our study should be seen as an explorative study that compares women and men under rather similar conditions in a specific context.

\section{Conclusion}

This study adds to the knowledge of similarities and differences between woman and men who are working in the same sector, in the same organization, and in the same occupation after adjusting for a variety of confounders. No gender differences were found in job, role, leadership, or organizational characteristics of the work climate. The differences that did emerge (in workgroup characteristics and health complaints) were all to the disadvantage of women. The main gender difference in the predictors of health complaints concerned the cohesiveness and cooperation of the workgroup. The workgroup served as a resource to reduce health complaints only for men physicians. This indicates that how the social circumstances among women and men physicians relate to gender differences in health are worth to explore further.

Despite some limitations, pointing at the difficulties in investigating women and men during similar conditions, this study shows that the gender differences that appear in the large structures of the gender-segregated labor market, to some extent also seem present for women and men who work in the same sector, the same organization, and in the same occupation. With this explorative study, we hope to inspire more research that takes into account the fact that women and men, to a large extent, work in different sectors, occupations, and positions, and that these differences may impact on women's and men's subjective experiences of their work environment. This, in turn, may relate to gender differences in health. 


\section{Funding}

Helena Falkenberg was supported by a fellowship from FAS Marie Curie International Postdoc (2012-0091). Petra Lindfors was supported by FORTE Grant No. 2009-1758 to Stockholm Stress Center, a center of excellence. The data collection was funded by a grant from FAS to Magnus Sverke (Grant No. 2003-0310).

\section{Acknowledgment}

A previous version of this study was included in Helena Falkenberg's doctoral thesis.

\section{References}

André-Petersson, L., Engström, G., Hedblad, B., Janzon, L. \& Rosvall, M. (2007). Social support at work and the risk of myocardial infarction and stroke in women and men. Social Science \& Medicine, 64(4): 830-841. doi: http://dx.doi.org/10.1016/j.socscimed.2006.10.020.

Arnetz, B.B. (2001). Psychosocial challenges facing physicians of today. Social Science \& Medicine, 52(2): 203-213. doi: http://dx.doi.org/10.1016/S0277-9536(00)00220-3.

Bakker, A.B. \& Demerouti, E. (2007). The Job Demands-Resources model: State of the art, Journal of Managerial Psychology, 22(3): 309-328. doi: http://dx.doi.org/10.1108/0268394 0710733115.

Beehr, T.A., Walsh, J.T. \& Taber, T.D. (1976). Relationships of stress to individually and organizationally valued states: Higher order needs as a moderator, Journal of Applied Psychology, 61(1): 41-47. doi: http://dx.doi.org/10.1037/0021-9010.61.1.41.

Campos-Serna, J., Ronda-Pérez, E., Artazcoz, L., Moen, B.E. \& Benavides, F.G. (2013). Gender inequalities in occupational health related to the unequal distribution of working and employment conditions: A systematic review, International Journal for Equity in Health, 12(1): 12-57. doi: http://dx.doi.org/10.1186/1475-9276-12-57.

Cronbach, L.J. (1951). Coefficient alpha and the internal structure of tests, Psychometrica, 16(3): 297-334. doi: http://dx.doi.org/10.1007/BF02310555.

D’Amato, A. \& Burke, M.J. (2008). Psychological and organizational climate research: Contrasting perspectives and research traditions [Special issue], European Journal of Work and Organizational Psychology, 17(1). doi: http://dx.doi.org/10.1080/13594320701666742.

De Koninck, M., Bergeron, P. \& Bourbonnais, R. (1997). Women physicians in Quebec, Social Science \& Medicine, 44(12): 1825-1832. doi: http://dx.doi.org/10.1016/S0277-9536(96) 00292-4.

Edwards, N., Kornacki, M.J. \& Silversin, J. (2002). Unhappy doctors: What are the causes and what can be done? British Medical Journal, 324(7341): 835-838. doi: http://dx.doi. org/10.1136/bmj.324.7341.835.

Ekvall, G. \& Arvonen, J. (1994). Leadership profiles, situation and effectiveness, Creativity and Innovation Management, 3(3):139-161.doi: http://dx.doi.org/10.1111/j.1467-8691.1994. tb00168.x.

Emslie, C., Hunt, K. \& Macintyre, S. (1999). Problematizing gender, work and health: The relationship between gender, occupational grade, working conditions and minor morbidity in full-time bank employees, Social Science \& Medicine, 48(1): 33-48. doi: http://dx.doi. org/10.1016/S0277-9536(98)00287-1.

Eriksson, K. (2003). Manligt läkarskap, kvinnliga läkare och normala kvinnor: Köns- och läkarskapande symbolik, metaforik och praktik. [Male physicianship, female physicians and normal women: The symbolical, metaphorical and practical doing(s) of gender 
and physicians]. Doctoral dissertation, Department of Sociology: Uppsala University, Sweden.

Eurostat. (2008). The life of women and men in Europe: A statistical portrait. Luxembourg: Office for Official Publications of the European Communities.

Goldberg, D. (1978). Manual of the General Health Questionnaire. Windsor: National Foundation for Educational Research.

Hackman, J.R. \& Oldham, G.R. (1975). Developent of the Job Diagnostic Survey, Journal of Applied Psychology, 60(2): 159-170. doi: http://dx.doi.org/10.1037/h0076546.

Härenstam, A., Westberg, H., Karlqvist, L., Leijon, O., Rydbeck, A., Waldenström, K., Nise, G. \& Jansson, C. (2000). Hur kan könsskillnader i arbets-och livsvillkor förstås? Metodologiska och strategiska aspekter samt sammanfattning av MOA-projektets resultat ur ett könsperspektiv. [How can gender differences in working and living conditions be understood? Methodological and strategic aspects and summary of the MOA project results from a gender perspective], Arbete \& Hälsa [Work \& Health], 15: 1-166.

James, L.A. \& James, L.R. (1989). Integrating work environment perceptions: Explorations into the measurement of meaning, Journal of Applied Psychology, 74(5): 739-751. doi: http://dx.doi.org/10.1037/0021-9010.74.5.739.

James, L.R. \& Sells, S.B. (1981). Psychological climate: Theoretical perspectives and empirical research. In Magnusson, D. (Ed.), Toward a psychology of situations: An interactional perspective. Hillsdale, NJ: Lawrence Erlbaum, pp. 275-295.

Jefferson, L., Bloor, K. \& Spilsbury, K. (2015). Exploring gender differences in the working lives of UK hospital consultants, Journal of the Royal Societal of Medicine, 0(0): 1-8. doi: http://dx.doi.org/10.1177/0141076814558523.

Johnson, J.V., Hall, E.M. \& Theorell, T. (1989). Combined effects of job strain and social isolation on cardiovascular disease morbidity and mortality in a random sample of the Swedish male working population, Scandinavian Journal of Work, Environment \& Health, 15(4): 271-279.

Karasek, R. \& Theorell, T. (1990). Healthy work: Stress productivity, and the reconstruction of working life. New York: Basic Books.

Krantz, G., Berntsson, L. \& Lundberg, U. (2005). Total workload, work stress and perceived symptoms in Swedish male and female white-collar employees, European Journal of Public Health, 15(2): 209-14. doi: http://dx.doi.org/10.1093/eurpub/cki079.

Lewis, C. \& Mathiassen, S.E. (2013). Belastning, genus och hälsa i arbetslivet: En kunskapssammanställning [Workload, gender and health at work: A literature review]. Stockholm: Arbetsmiljöverket [Swedish Work Environment Authority].

Liu, C., Spector, P.E. \& Shi, L. (2008). Use of both qualitative and quantitative approaches to study job stress in different gender and occupational groups, Journal of $\mathrm{Occu}$ pational Health Psychology, 13(4): 357-370. doi: http://dx.doi.org/10.1037/10768998.13.4.357.

Lundberg, U. \& Frankenhaeuser, M. (1999). Stress and workload of men and women in high-ranking positions, Journal of Occupational Health Psychology, 4(2): 142-151. doi: http://dx.doi.org/10.1037/1076-8998.4.2.142.

McDonough, P. \& Walters, V. (2001). Gender and health: Reassessing patterns and explanations, Social Science \& Medicine, 52(4): 547-559. doi: http://dx.doi.org/10.1016/S02779536(00)00159-3.

Miller, K. \& Clark, D. (2008). "Knife before wife": An exploratory study of gender and the UK medical profession, Journal of Health Organization and Management, 22(3): 238-53. doi: http://dx.doi.org/10.1108/14777260810883521.

Muhonen, T. \& Torkelson, E. (2003). The Demand-Control-Support Model and health among women and men in similar occupations, Journal of Behavioral Medicine, 26(6): 601-613. doi: http://dx.doi.org/10.1023/A:1026257903871. 
Narayanan, L., Menon, S. \& Spector, P. (1999). A cross-cultural comparison of job stressors and reactions among employees holding comparable jobs in two countries, International Journal of Stress Management, 6(3): 197-212. doi: http://dx.doi. org/10.1023/A:1021986709317.

Nunnally, J. C. (1978). Psychometric theory. New York: McGraw-Hill.

Nystedt, L. (1992). The work environment of army officers: Results of study 1 on work environment, turnover, and health. Stockholm: Försvarets forskningsanstalt, FOA rapport nr C50093-5.3.

Parker, C.P., Baltes, B.B., Young, S.A., Huff, J.W., Altmann, R.A., Lacost, H.A. \& Roberts, J.E. (2003). Relationships between psychological climate perceptions and work outcomes: A meta-analytic review. Journal of Organizational Behavior, 24(4): 389-416. doi: http:// dx.doi.org/10.1002/job.198.

Persson, R., Hansen, Å.-M., Ohlsson, K., Balogh, I., Nordander, C. \& Ørbæk, P. (2009). Physiological and psychological reactions to work in men and women with identical job tasks. European Journal of Applied Physiology, 105(4): 595-606. doi: http://dx.doi. org/10.1007/s00421-008-0939-8.

Risberg, G. (2004). "I am solely a professional - neutral and genderless" On gender bias and gender awareness in the medical profession. Doctoral dissertation, Department of Public Health and Clinical Medicine: Umeå University, Sweden.

Riska, E. (2001). Towards gender balance: But will women physicians have an impact on medicine? Social Science and Medicine, 52(2): 179-187. doi: http://dx.doi.org/10.1016/ S0277-9536 (00)00218-5.

Rizzo, J.R., House, R.J. \& Lirtzman, S.I. (1970). Role conflict and ambiguity in complex organizations, Administrative Science Quarterly, 15(2): 150-163. doi: http://dx.doi.org/ $10.2307 / 2391486$.

Robinson, G.E. (2003). Stresses on women physicians: Consequences and coping techniques, Depression and Anxiety, 17(3): 180-189. doi: http://dx.doi.org/10.1002/da.10069.

Robinson, S.L. (1996). Trust and breach of the psychological contract, Administrative Science Quarterly, 41(4): 574-599. doi: http://dx.doi.org/10.2307/2393868.

Roxburgh, S. (1996). Gender differences in work and well-being: Effects of exposure and vulnerability, Journal of Health and Social Behavior, 37(3): 265-277.

Siegrist, J. (1996). Adverse health effects of high-effort/low-reward conditions, Journal of Occupational Health Psychology, 1(1): 27-41. doi: http://dx.doi.org/10.1037/10768998.1.1.27.

Statistics Sweden (2014). Undersökningarna av Levnadsförhållanden (ULF/SILC) [The living conditions survey (ULF/SILC)]. http://www.scb.se/sv/Hitta-statistik/Statistik-efter-amne/ Levnadsforhallanden/Levnadsforhallanden/Undersokningarna-av-levnadsforhallanden-ULFSILC/\#c li 354235. Accessed 5 November 2015.

Statistics Sweden (2002). Arbetsmiliön 2001 [The Work Environment 2001]. AM 68 SM 0201. Statistics Sweden and Swedish Work Environment Authority.

Swedish Work Environment Authority (2014). Arbetsmiljön 2013 [The Work Environment 2013]. Report 2014:3. Stockholm: Swedish Work Environment Authority

Sverke, M., Hellgren, J., Näswall, K., Chrumbolo, A., De Witte, H., \& Goslinga, S. (2004), Job insecurity and union membership: European unions in the wake of flexible production. P.I.E.-Peter Lang: Brussels.

Sverke, M., Hellgren, J., Näswall, K., Göransson, S., \& Öhrming, J. (2008). Employee participation in organizational change: Investigating the effect of proactive vs. reactive implementation of downsizing in Swedish hospitals, German Journal of Human Resource Research, 22(2): 111-129.

Sverke, M., Hellgren, J., \& Öhrming, J. (1999). Organizational restructuring and health care work: A quasi-experimental study. In le Blanc, P.M., Peeters, M.C.W., Büssing, A., and 
Schaufeli, W.B. (Eds.), Organizational Psychology and Health Care: European Contributions. Rainer Hampp, Munich, pp. 15-32.

Sverke, M., Sjöberg, A., (1994). Dual commitment to company and union in Sweden: An examination of predictors and taxonomic split methods, Economic and Industrial Democracy, 15(4): 531-564. doi: http://dx.doi.org/10.1177/0143831X94154003.

Taylor, J.C. \& Bowers, D.G. (1972). Survey of organizations: A machine scored standardized questionnaire instrument. Michigan: Institution for Social Reseach.

Van De Vijver, F. J., Chasiotis, A. \& Breugelmans, S. M. (2011). Fundamental questions in cross-cultural psychology. Cambridge: Cambridge University Press.

Vandenberg, R. J. \& Lance, C. E. (2000). A review and synthesis of the measurement invariance literature: Suggestions, practices, and recommendations for organizational research, Organizational Research Methods, 3(1): 4-70.

West, C. (1993). Reconceptualising gender in physician-patient relationship, Social Science and Medicine, 36(1): 57-66. doi: http://dx.doi.org/10.1177/109442810031002.

World Economic Forum (2014). The global gender gap report 2014. Geneva: World Economic Forum. 